\title{
Tonle Sap ecosystem water quality index development and fish production
}

\author{
N. T. H. Yen ${ }^{1}$, K. Sunda ${ }^{1}$, S. Oishi ${ }^{1} \&$ K. Ikejima ${ }^{2}$ \\ ${ }^{I}$ Department of Civil Engineering, University of Yamanashi, Japan \\ ${ }^{2}$ Asian Institute of Technology, Bangkok, Thailand
}

\begin{abstract}
The Tonle Sap ecosystem of Cambodia is situated in the lower part of the Mekong River basin (MRB), the TS ecosystem water environment is influenced by $181,035 \mathrm{~km}^{2}$ of its catchments and water inflow from $4000 \mathrm{~km}$ in length of the upper Mekong River. The water quality index (WQI) was developed based on seven environmental chemical factors of DO, $\mathrm{NO}_{3}+\mathrm{NH}_{4}$, TOTP, TSS, temperature, $\mathrm{pH}$ and conductivity at Kampong Luong monitoring station during the period 1995 - 2002. On PCA, among 15 candidate parameters, the six most variation parameters of 'concentration of TSS $\mathrm{mg} \mathrm{l}^{-1}$ ', 'temperature $\mathrm{C}$ degree', 'conductivity $\mathrm{mS} \mathrm{m}^{-1}$, 'ratio between $\mathrm{N}$ and $\mathrm{P}$ ', 'average monthly variation of $\mathrm{NO}_{3}+\mathrm{NH}_{4} \mathrm{~N}$ ', 'average monthly variation of $\mathrm{pH}$ ', were identified and selected to constitute the WQI. Each parameter was scored as 1, 3 and 5 and narrated, in order, as poor, fair and good conditions. The yearly WQI score was calculated from these six parameter scores in the relative year. The WQI showed that the highest score of 4.3 was in 1996, while the lowest scores were of 1.3 and 1.0 in 2002 and 1998. Importantly, the WQI was significantly $(P<0.05)$ correlated with the 'dai' fish catch $\left(\mathrm{r}^{2}=0.858\right)$ and the fish biological group 4 ( $r$-species) $\left(\mathrm{r}^{2}=0.75\right)$ during the period 1995-2002 indicating that the index was sensitive to reflect the relation between water quality condition and fish production. Then the WQI should be considerably used as the biological monitoring tool for water quality - fish production assessment. The correlations $(\mathrm{P}<0.05)$ between WQI and fish families of Gyrinocheilidae and Cyprinidae indicated these fish families should be considered to be used as the TS ecosystem water quality bioindicators. Keywords: Tonle Sap ecosystem, water quality index, 'dai' fish catch, fish biological group, $k$ and $r$ strategy species and multi-parameters analysis.
\end{abstract}




\section{Introduction}

The Tonle Sap (TS) ecosystem, including the TS Great Lake and the TS River, in the lower part of the Mekong River Basin (MRB) is well known as the largest wetland having the highest biodiversity in Southeast Asia, Mok et al [1]. The TS Lake functions as the hatching and nursing grounds for migrant and non-migrant fish species, Sarkkula et al [2]; at least 178 species have been found from fish catches during the period 1995-2002. This ecosystem contributes about $60 \%$ of the total inland catch of Cambodia, Csavas et al [3] and WB [4] and 60\% protein intake of the entire Cambodian population, Ahmed et al [5].

The TS lake water level can rise up to $14 \mathrm{~m}$ in depth and enable the lake to expand about $10,000 \mathrm{~km}^{2}$ of water surface in the wet season (June - October) due to the Mekong River inflow and its catchments runoff, and the water level can fall down to $1 \mathrm{~m}$ in depth at about $2,500 \mathrm{~km}^{2}$ surface area due to receding water from the lake to the Mekong delta in the dry season (Nov - May), Hak and Piseth [6] and MRC [7]. The TS ecosystem water quality is strongly influenced by land use and the economic activities of 50 millions residents within 700,000 $\mathrm{km}^{2}$ catchments of MRB, Chu et al [8]. Degrading watersheds and unsustainable resources uses affected by shifting cultivation, increased logging, and encroachment, increasing agro-chemical from agricultural intensification and expansion, increasing urban and industrial waste at national and or transboundary scales, UNEP and MRC [9]. The WUP-FIN Project's water quality modeling showed that 4,300,00 tons of TSS annually remaining in the TS lake from Mekong river inflow contributed 1,350 tons of TOTP and 8,500 tons of $\mathrm{NO}_{3}{ }^{-}$, Sarkkula et al [2]. The TS Lake is also strongly influenced by the $181,035 \mathrm{~km}^{2}$ catchments land use, ADB [10]. In Cambodia, the current deforestation rate is estimated at 250,000 ha toward $1.4 \%$ of total land area annually, Chu [8]. The flooded forest declined from 1,000,000 ha in 1973 to 450,000 ha in 1997; in contrast, the rain fed and receding rice areas increase of $1,100 \mathrm{~km}^{2}$ UNEP [11]. During period 1993-1998, the numbers of industrial factories increase from 308 to 858, UNEP [11]. In 1996, the examination of pollution at three provinces around the TS Lake including Battam Bang, Siem Reap and Kampong Thom, showed that the deposited solid waste was estimated 12-15.36 tons day ${ }^{-1}$, the concentration of BOD was 5 to $6.4 \mathrm{mg} \mathrm{l}^{-1}$; TSS was 11 to $14.08 \mathrm{mg} \mathrm{l}^{-1}$, total $\mathrm{N}$ was 0.9 to $1.15 \mathrm{mg} \mathrm{l}^{-1}$ and total $\mathrm{P}$ was 0.25 to $0.32 \mathrm{mg} \mathrm{l}^{-1}$, UNEP [11]. Naturally, organic matter decomposition of flooded vegetation during the flood duration contributes a great amount of nutrient into the lake water environment, Lamberts [12]. Because of nutrient enrichment, the algae bloom has been often observed and weed infestation increased by water hyacinth and Mimosa pigra, Mok et al [1].

The WQI, one kind of the monitoring approach, is widely applied in the United States, Canada and Europe. Nine common parameters of temperature, $\mathrm{pH}$, total fecal coliform bacteria, $\mathrm{TSS}, \mathrm{NO}_{3}$, total $\mathrm{P}$, turbidity, $\mathrm{DO}$ and BOD are widely used as the indicators to evaluate and monitor water quality EPA [13]. In the TS ecosystem, since 1995,7 water quality parameters of $\mathrm{DO}, \mathrm{NO}_{3}, \mathrm{TOTP}$, TSS, temperature, $\mathrm{pH}$ and conductivity have been monthly measured at four monitoring stations of Phnom Penh (PP), Pekdam (PK), Kampong Chhnang 
(KC) and Kampong Luong (KL) by the Mekong River Commission (MRC) (the square spots in Figure 1). Additionally, there is some water quality data available of the TS Lake conducted by the WUP-FIN water utilization Project in 2001 and 2002 (round spots in Figure 1). There is also available data of the TS fisheries by 'dai' fish catch monitoring program under MRC-Danida Project during 19952005. The 'dai' fish is one kind of industrial fishing method operating along the TS River during the receding duration (water outflow from the TS Lake to the Mekong main stream via the TS River). The numbers of 'dai' is regulated by Cambodian Department of Fisheries, there were 63 'dai' annually operating during the sample period 1995-2002. Then the 'dai' fish catch can be used as the indicator of the TS ecosystem fish production. The aims of this study were: (1) to study about TS ecosystem water quality condition; (2) to identify the potential water quality parameters, which can reflect the TS ecosystem fish production/ catch and (3) to constitute a WQI based on fish catch/ production to provide a monitoring tool for the TS ecosystem water quality -fish production assessment.

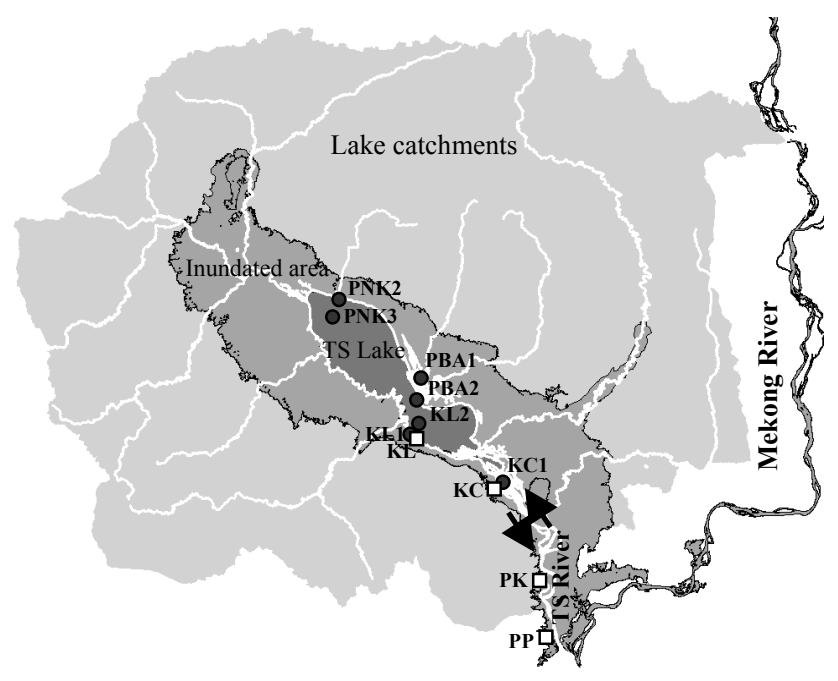

Figure 1: Tonle Sap ecosystem, its catchments, tributaries, inundated area and WQ sampling sites.

\section{Methods}

The schematic of the WQI development was showed in Figure 2. The water quality data at four MRC stations was analyzed to understand the water quality condition and zonation along the TS River and the TS Lake, while the WUP-FIN Project's data was analyzed to illustrate the TS Lake water quality spatially and to deduce the possible application of KL station data representing for the TS Lake water condition. Then, the data at KL station would be used to develop WQI for the TS ecosystem. Both the concentration and average monthly variation of seven water quality parameters at KL station during 1995-2002 were 
analyzed to identify the potential parameters for index development. Additionally, the parameter of the ratio between $\mathrm{N}$ and $\mathrm{P}$ indicating for oligotrophic, mesotrophic, eutrophic and hypereutrophic were also taken into account. To ensure the sensitiveness of the index in reflecting the relation between water quality conditions and fish production, then the parameters which having above 0.75 correlation coefficient on principal component analysis (PCA) were preferably selected to constitute the index. In case, two of the concentration and the average monthly variation of a given parameter were also having high correlation coefficients, the parameter of concentration was priority selected alternatively. Two lower $a_{i}$ and upper $b_{i}$ thresholds were identified for each parameter. The parameter values between two thresholds $a_{i}$ and $b_{i}$ were scored as 3 and narrated as the fair water quality condition, while the values less than $\mathrm{a}_{\mathrm{i}}$ or more than $b_{i}$ values were scored as 1 or 5 and narrated as the poor or good conditions depending on their positively or negatively correlated with "dai" fish catch individually. The yearly WQI was calculated by the average of all parameter scores in the relative year and the number (n) of parameters as the followed: $\mathrm{WQI}=\left(\right.$ Score $_{\text {parameter }} 1+$ Score $_{\text {parameter }} 2 \ldots+\ldots$ Score $\left._{\text {parameter }} n\right) / n$ parameters. The yearly water quality classification was based on the index by the following criteria: very good $=4-5$; good $=3-4$; fair $=2-3$ and poor $=$ less than 2 .

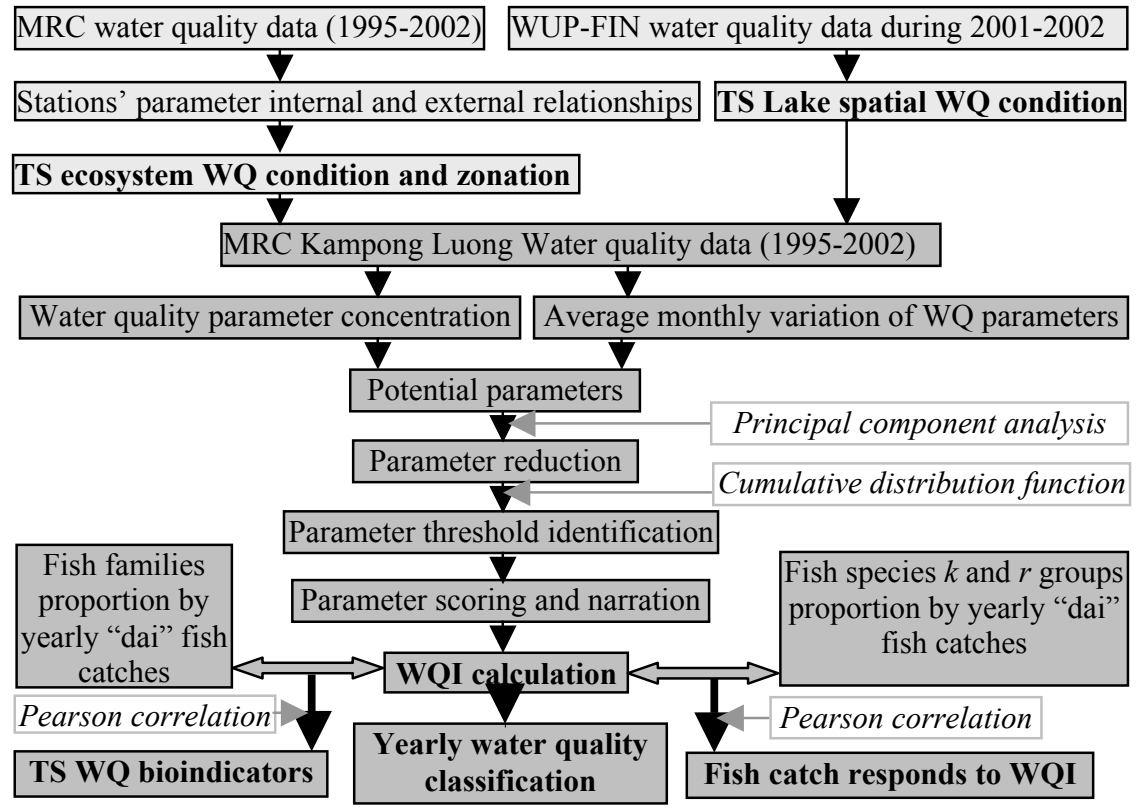

Figure 2: $\quad$ Tonle Sap ecosystem Water Quality Index development.

The PCA was used to illustrate the multi-relationship within and between water quality parameters and "dai" fish catch for further step of parameter selection and scoring narration. Pearson correlation test was used for: (1) testing 
the negative or positive correlations between water quality parameters and "dai" fish catch; (2) testing the correlations between the constituted WQI and "dai" fish catch and fish $k$ and $r$ biological groups' catches. The cumulative distribution function (CDF) was used to identify the lower $a_{i}$ and upper $b_{i}$ threshold values for each given parameter. The lower $a_{i}$ and upper $b_{i}$ thresholds enabled to divide the parameter values into three distinct different conditions. The $k$ and $r$ strategy fish species biological groups were used from our previous research results, Nguyen et al [14].

\section{Results}

\subsection{Tonle Sap ecosystem water quality zonation}

Data overview showed that $134.35 \mathrm{mg} \mathrm{l}^{-1}$ of TSS concentration in KL station was very different from the rest three stations which having about $50 \mathrm{mg} \mathrm{l}^{-1}$. The conductivity was different among four stations; the highest was of $9.75 \mathrm{mS} \mathrm{m}^{-1}$ in $\mathrm{KL}$ station while the lowest was of $8.66 \mathrm{mS} \mathrm{m}^{-1}$ in $\mathrm{KC}$ station. While an average 7.09 of $\mathrm{pH}$ was at $\mathrm{KL}$ station. In contrast, the concentrations of $\mathrm{DO}$, $\mathrm{NO}_{3}+\mathrm{NH}_{4}$ and TOTP individually were similar among four stations (e.g., DO: $5.23-5.8 \mathrm{mg} \mathrm{l}^{-1} ; \mathrm{NO}_{3}+\mathrm{NH}_{4}: 0.26-0.27 \mathrm{mg} \mathrm{l}^{-1}$ and TOTP: $0.02-0.03 \mathrm{mg} \mathrm{l}^{-1}$ ). The station's internal parameter multi-relationship analyses (solid lines in Figure 3) showed that the parameter multi-relationship at KC station was the most complexity, in contrast, the most simplicity was at KL station (Figure 3), while the PP and PK stations were more similar. One straight line relationship of Conductivity- $\mathrm{pH}$ - DO was statistically significant formed at the same four stations (Figure 3). TSS was positively correlated with conductivity; pH; DO; and or temperature in $\mathrm{PP}, \mathrm{PK}$ and $\mathrm{KC}$, but these correlations were not occurred in $\mathrm{KL}$ station (Figure 3). In $\mathrm{KC}$ and $\mathrm{KL}$ stations, TSS concentrations were positively correlated with $\mathrm{NO}_{3}+\mathrm{NH}_{4} \mathrm{~N}$ concentrations; however, this correlation was not formed in PP and PK stations. DO concentrations were positively correlated with TSS concentration in PP and PK stations, while there was a negative correlation between $\mathrm{DO}$ concentration and $\mathrm{NO} 3+\mathrm{NH}_{4} \mathrm{~N}$ concentration in $\mathrm{KC}$ station. However, DO concentration in $\mathrm{KL}$ station was quite independent (Figure 3). Station's external relationship analyses (dot line in Figure 3) showed that four parameters, including $\mathrm{NO}_{3}+\mathrm{NH}_{4} \mathrm{~N}$; TOTP; temperature and conductivity, were strongly correlated $(P<0.05$ or $P<0.001)$ among four stations. There was no correlation of $\mathrm{pH}$ between $\mathrm{KL}$ and $\mathrm{PK}$ stations (Figure 3). Similarly, there was no correlation of TSS concentration between KL station and PK and PP stations (Figure 3). Especially, the station's external relationship of DO concentration was only formed between PP and PK stations.

\subsection{Tonle Sap Lake spatial water quality}

During Jun 2001 - Nov 2002, there 2000 water quality samples in the TS Lake and its tributaries were conducted by WUP-FIN Project. However, only seven sampling sites in the open and coastal areas of lake have more data available of seven parameters of temperature, TOTP, $\mathrm{PO}_{4} \mathrm{P}, \mathrm{NH}_{4} \mathrm{~N}, \mathrm{NO}_{3}, \mathrm{DO}$ and $\mathrm{pH}$ (Table 
1). Two stations of $\mathrm{KL1}$ and $\mathrm{KCl}$ (highlighted) were the same places with two stations of KL and KC of the MRC's monitoring stations. In Table 1, the coastal KL1 station water quality was more similar to other coastal and open lake stations compared to stream (PBA1) and the lake river delta (KC1) stations. Additionally, the Pearson correlation test also showed that the water quality parameters in KL1 station were more significantly correlated with those of that in other stations. Then it deduced that the MRC's KL station water quality would be representing the TS Lake environment and was used for further steps of WQI development.

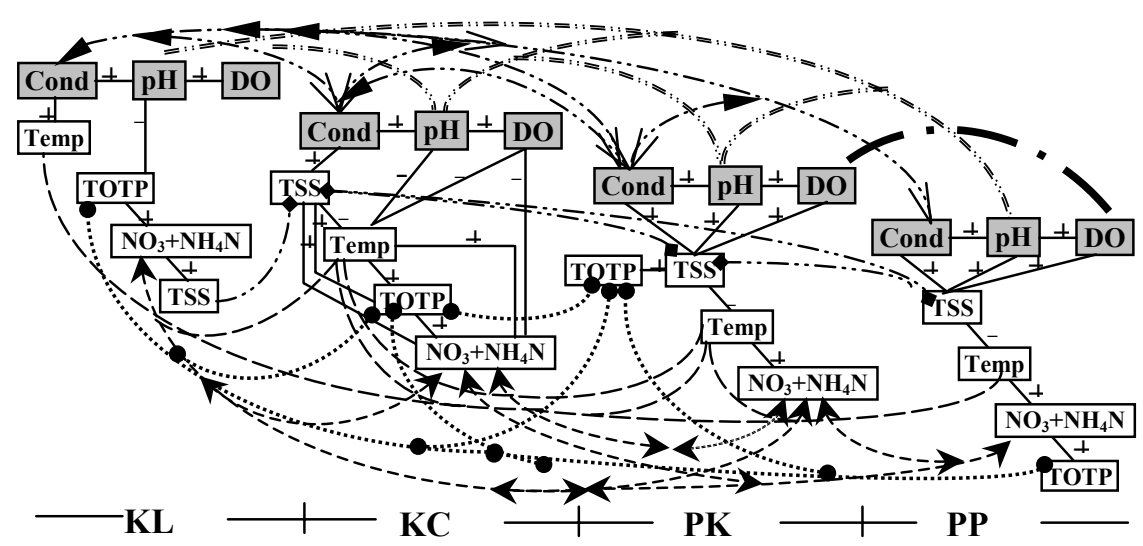

Figure 3: The stations' internal and external relationship patterns among seven parameters. (+) and (-) indicate for positive or negative correlation between two parameters within station. The solid lines indicate for station internal multi-relationship among parameters; the dot lines indicate for the station external relationship of each particular parameter. Cond is conductivity.

Table 1: Tonle Sap Lake spatial water quality (source from WUP-FIN Project).

\begin{tabular}{|c|c|c|c|c|c|c|c|c|}
\hline $\begin{array}{c}\text { Habitat } \\
\text { type }\end{array}$ & Station & $\begin{array}{c}\text { Temp } \\
\left({ }^{\circ} \mathrm{C}\right)\end{array}$ & $\begin{array}{c}\mathrm{TOTP} \\
\left(\mathrm{mg} \mathrm{l}^{-1}\right)\end{array}$ & $\begin{array}{c}\mathrm{PO}_{4} \mathrm{P} \\
\left(\mathrm{mg} \mathrm{l}^{-1}\right)\end{array}$ & $\begin{array}{c}\mathrm{NH}_{4} \mathrm{~N} \\
\left(\mathrm{mg} \mathrm{l}^{-1}\right)\end{array}$ & $\begin{array}{c}\mathrm{NO}_{3} \\
\left(\mathrm{mg} \mathrm{l}^{-1}\right)\end{array}$ & $\begin{array}{c}\mathrm{DO} \\
\left(\mathrm{mg} \mathrm{l}^{-1}\right)\end{array}$ & $\mathrm{pH}$ \\
\hline Coastal & PNK2 & 29.28 & 0.011 & 0.005 & 0.027 & 0.170 & 6.85 & 7.67 \\
\hline Coastal & PBA2 & 29.27 & 0.011 & 0.005 & 0.036 & 0.067 & 6.05 & 7.44 \\
\hline Coastal & KL1 & 30.28 & 0.014 & 0.005 & 0.030 & 0.114 & 5.94 & 7.36 \\
\hline Open & PNK3 & 29.18 & 0.010 & 0.003 & 0.038 & 0.048 & 4.33 & 7.14 \\
\hline Open & KL2 & 28.67 & 0.014 & 0.005 & 0.059 & 0.103 & 6.72 & 7.52 \\
\hline Stream & PBA1 & 29.77 & 0.024 & 0.012 & 0.069 & 0.283 & 3.50 & 7.11 \\
\hline Delta & KC1 & 30.03 & 0.014 & 0.004 & 0.031 & 0.048 & 5.41 & 7.22 \\
\hline
\end{tabular}

\subsection{Tonle Sap ecosystem and 'dai' fish species biological group and catch}

The data and information of this portion were used from our previous research result, which is ongoing published in International Journal of Ecological 
economic and Statistic, Nguyen et al [14]. A total of 178 fish species, including 154 species found in Dai catches during 1995-2002 and 104 species found in lot and mobile gear catches during 1994-1997, were classified by clustering analysis (at $85 \%$ of similarity) into four biological groups in the $k$ and $r$ strategist spectrum based on nine biological attributes (Figure 4). Nine biological attributes included maximum length; growth coefficient; natural mortality; life span; age at the first maturity; resilience; main food; trophic level and food consumption. The $k$-strategist is large fish-slow reproducing and growing with few offspring and high energy demand. In contrast, $r$-strategist is small fish-fast reproducing and growing with many offspring and low energy demand. Because of species diversity within a family of fish, then one fish family would be classified into more than one $k$ or $r$ species group. Then, the bigger body size species of Pangassidae and Siluridae belonged to group 1; Bagaridae, Cyprinidae and Sciaenidae belonged to group 2. While smaller body size species of Ambassidae, Cyprinidae, Gyrinocheilidae, Pangassidae belonged to group 3 and the very small body size species of Clupeidae, Cortibidae, Cyprinidae, Siluridae and Soleidae families belonged to group 4. The contribution of each fish biological group in yearly 'dai' fish catch is shown in Table 2. The catch ratios between $r$ (group 3 and 4) species and $k$ (group 1 and 2) species from 1995 to 2002 were tended decreasingly (Table 2 ).

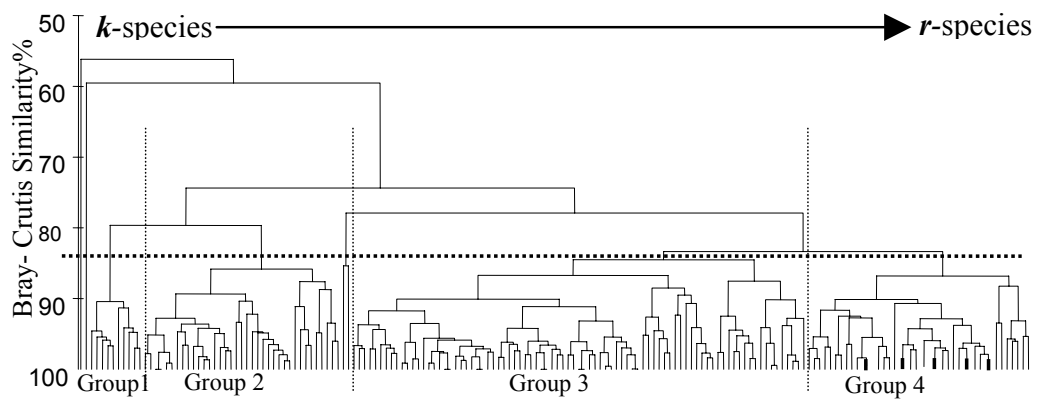

Figure 4: Dendrogram of the TS ecosystem fish species biological groups.

\subsection{Tonle Sap water quality index development}

\subsubsection{Potential parameters identification and selection}

Fifteen potential parameters were identified based on the parameters' concentrations and their average monthly variations and the ratio between $\mathrm{NO}_{3}+\mathrm{NH}_{4} \mathrm{~N}$ and TOTP from KL station data. PCA analysis illustrated that almost all water quality parameters were negatively correlated with the total 'dai' fish catch on component 1 (41.28\%) (Figure 5(a)). The $\mathrm{NO}_{3}+\mathrm{NH}_{4} \mathrm{~N}$ and $\mathrm{pH}$ concentrations were not high correlated with total 'dai' fish catch, however, their average monthly variations were significantly correlated with total 'dai' fish catch. Both concentrations and average monthly variation of DO were very weak correlated with total 'dai' fish catch. Therefore, only six parameters (bold labels in Figure 5(a)) were selected and used to constitute the WQI. Those parameters 
included TSS, temperature, conductivity, ratio of $\mathrm{N}$ and $\mathrm{P}$, and two parameters of average monthly variations of $\mathrm{NO}_{3}+\mathrm{NH}_{4} \mathrm{~N}$ and $\mathrm{pH}$ and their yearly values were shown in Table 2 . The yearly water quality distribution patterns were shown in Figure 5(b), of which, the years 1996, 1995, 2002 and 2001 were closed to the total 'dai' fish catch direction, while the years 1998 and 2002 were closed to the water quality parameters direction, which being opposite direction with the total 'dai' fish catch.

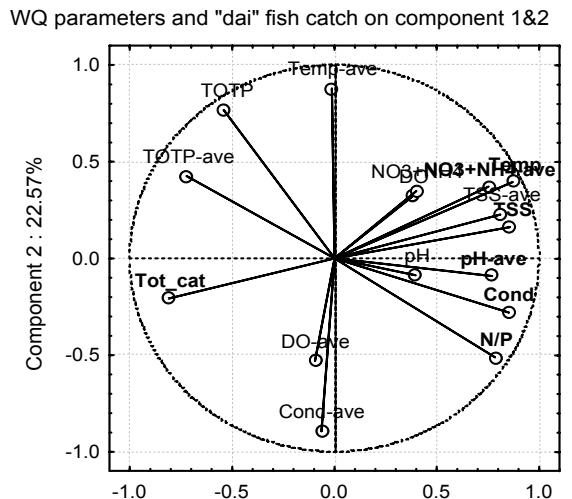

(a)

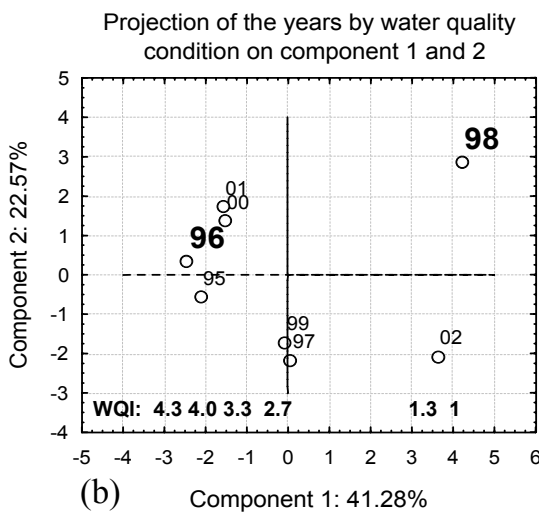

Figure 5: PCA analysis of total "dai" fish catch and potential water quality parameters (a) and years distribution (b). Note: in the (a) figure DO and $\mathrm{DO}$-ave $=$ average monthly dissolved oxygen concentration and variation $\left(\mathrm{mg} \mathrm{l}^{-1}\right) ; \mathrm{NO}_{3}+\mathrm{NH}_{4} \mathrm{~N}$ and $\mathrm{NO}_{3}+\mathrm{NH}_{4} \mathrm{~N}$-ave = average monthly $\mathrm{NO}_{3}+\mathrm{NH}_{4} \mathrm{~N}$ concentration and variation $\left(\mathrm{mg} \mathrm{l}^{-1}\right)$ (note: total of $\mathrm{NO}_{3}{ }^{-}$and $\mathrm{NH}_{4} \mathrm{~N}$ concentrations); TOTP and TOTP-ave $=$ average monthly total phosphate concentration and variation (mg $\mathrm{l}^{-}$ ${ }^{1}$ ), TSS = average monthly total suspended sediment concentration and variation $\left(\mathrm{mg} \mathrm{l}^{-1}\right)$; Temp and Temp-ave = average monthly temperature and variation $\left({ }^{\circ} \mathrm{C}\right)$; Cond and Cond-ave $=$ average monthly conductivity and its variation $\left(\mathrm{mS} \mathrm{m}^{-1}\right) ; \mathrm{pH}$ and $\mathrm{pH}$-ave $=$ average monthly $\mathrm{pH}$ and its variation $\mathrm{N} / \mathrm{P}=$ ratio between $\mathrm{NO}_{3}+\mathrm{NH}_{4} \mathrm{~N}$ and TOTP. Tot_cat = total "dai" fish catch (ton) by year. In the (b) figure $\mathrm{WQI}=$ water quality index; the number indicated the year (e.g. 98 was year 1998).

\subsubsection{Parameters thresholds identification, score, narration and index calculation}

By CDF analysis, two lower $a_{i}$ and upper $b_{i}$ thresholds of individual parameter were identified. All six selected parameters were negatively correlated with total 'dai' fish catch (Figure 5(a)), then the parameters were scored and narrated inversely with the increase of parameter values. Then all values below $a_{i}$ of a given parameter were scored as 5 and narrated as good condition. In contrast, the parameter values above $b_{i}$ were scored as 1 and narrated as poor condition. The yearly parameter scores were shown in parentheses in Table 2 . The index 
calculation showed that the highest TS ecosystem WQI was of 4.3 in year 1996, while the lowest was of 1.0 and 1.3 (maxima of 5) in the years 1998 and 2002 respectively (Table 2). During 1995 to 2002, the yearly water quality classification based on WQI showed that the water quality in 1996 was in "very good" condition, four years were in "good" condition, one year was in "fair" condition, and two years were in "poor" condition (Table 2). The gradient of WQI by years is shown in Figure 5(b).

Table 2: $\quad$ Selected water quality parameters values, scores and "dai" fish catch.

\begin{tabular}{|c|c|c|c|c|c|c|c|c|c|c|c|c|c|}
\hline \multirow{3}{*}{ Year } & \multicolumn{6}{|c|}{$\begin{array}{l}\text { Selected water quality parameters and } \\
\text { score }\end{array}$} & \multirow{3}{*}{$\begin{array}{c}\text { WQI } \\
\text { and } \\
\text { rating }\end{array}$} & \multicolumn{6}{|c|}{$\begin{array}{l}\text { Total "dai" fish catch and } \mathrm{k} \text { and } r \\
\text { fish species groups (tons) }\end{array}$} \\
\hline & TSS & Tem & Cond & $\mathrm{N} / \mathrm{P}$ & $\mathrm{NO} 3+\mathrm{NH}_{4} \mathrm{~N}$ & $\mathrm{pH}-$ & & Total & Group & Group & Group & Group & \\
\hline & $\left(\mathrm{mg} \mathrm{l}^{-1}\right)$ & $\begin{array}{c}\mathrm{p} \\
\left({ }^{\circ} \mathrm{C}\right)\end{array}$ & & & $-\mathrm{a}$ & ave & & & 1 & 2 & 3 & 4 & $\mathbf{r} / \mathbf{k}$ \\
\hline 1995 & $\begin{array}{c}16.53 \\
(5)\end{array}$ & $\begin{array}{c}29.67 \\
(5)\end{array}$ & $\begin{array}{c}8.56 \\
(3)\end{array}$ & $\begin{array}{c}10.0 \\
(3)\end{array}$ & (5) & $\begin{array}{c}0.38 \\
(3)\end{array}$ & $\begin{array}{c}4 \\
(\mathbf{G})\end{array}$ & $\begin{array}{c}14,42 \\
8\end{array}$ & 706 & 622 & 3,341 & 9,170 & 9.4 \\
\hline 1996 & $\begin{array}{c}57.92 \\
(3)\end{array}$ & $\begin{array}{c}29.83 \\
(5)\end{array}$ & $\begin{array}{c}7.73 \\
(5)\end{array}$ & $\begin{array}{l}9.7 \\
(3)\end{array}$ & $\begin{array}{c}0.15 \\
(5)\end{array}$ & $\begin{array}{c}0.17 \\
(5)\end{array}$ & $\begin{array}{c}4.3 \\
(V G) \\
\end{array}$ & $\begin{array}{c}16,83 \\
4\end{array}$ & 545 & 803 & 5,822 & 9,257 & 11.2 \\
\hline 1997 & $\begin{array}{c}66.53 \\
(3) \\
\end{array}$ & $\begin{array}{c}29.75 \\
(5)\end{array}$ & $\begin{array}{l}8.3 \\
(3) \\
\end{array}$ & \begin{tabular}{|c|}
14.1 \\
$(1)$
\end{tabular} & $\begin{array}{c}0.17 \\
(3)\end{array}$ & $\begin{array}{c}0.27 \\
(5)\end{array}$ & $\begin{array}{l}3.3 \\
(\mathbf{G}) \\
\end{array}$ & $\begin{array}{c}14,60 \\
4\end{array}$ & 1,132 & 973 & 5,512 & 6,364 & 5.6 \\
\hline 1998 & $\begin{array}{c}118.9 \\
(1)\end{array}$ & $\begin{array}{c}30.58 \\
(1)\end{array}$ & $\begin{array}{c}9.41 \\
(1)\end{array}$ & $\begin{array}{c}13.2 \\
(1)\end{array}$ & $\begin{array}{l}0.3 \\
(1)\end{array}$ & $\begin{array}{c}0.62 \\
(1)\end{array}$ & $\begin{array}{c}1 \\
(\mathbf{P})\end{array}$ & 8,894 & 976 & 628 & 2,610 & 4,173 & 4.2 \\
\hline 1999 & $\begin{array}{c}22.21 \\
(5)\end{array}$ & $\begin{array}{c}29.75 \\
(5)\end{array}$ & $\begin{array}{l}9.17 \\
(1)\end{array}$ & $\begin{array}{c}12.3 \\
(1)\end{array}$ & $\begin{array}{c}0.19 \\
\text { (3) }\end{array}$ & $\begin{array}{c}0.62 \\
(1)\end{array}$ & $\begin{array}{l}2.7 \\
\text { (F) }\end{array}$ & $\begin{array}{c}11,48 \\
5\end{array}$ & 803 & 582 & 2,243 & 7,418 & 6.9 \\
\hline 2000 & $\begin{array}{c}32.43 \\
\text { (5) }\end{array}$ & $\begin{array}{c}29.96 \\
\text { (3) }\end{array}$ & $\begin{array}{c}7.77 \\
(5)\end{array}$ & \begin{tabular}{|l|}
11 \\
(3)
\end{tabular} & $\begin{array}{c}0.12 \\
(5)\end{array}$ & $\begin{array}{c}0.38 \\
(3)\end{array}$ & $\begin{array}{c}4 \\
\text { (G) }\end{array}$ & $\begin{array}{c}14,97 \\
4\end{array}$ & 857 & 1,120 & 4,273 & 8,140 & 6.3 \\
\hline 2001 & $\begin{array}{c}35.92 \\
(5) \\
\end{array}$ & $\begin{array}{c}29.95 \\
\text { (3) }\end{array}$ & $\begin{array}{l}8.32 \\
(3)\end{array}$ & \begin{tabular}{|l|}
7.8 \\
$(\mathbf{5})$ \\
\end{tabular} & $\begin{array}{c}0.17 \\
(3)\end{array}$ & $\begin{array}{c}0.27 \\
(5)\end{array}$ & $\begin{array}{c}4 \\
(\mathbf{G}) \\
\end{array}$ & $\begin{array}{c}13,73 \\
8 \\
\end{array}$ & 970 & 2,778 & 4,519 & 5,347 & 2.6 \\
\hline 2002 & $\begin{array}{l}99.5 \\
\text { (1) }\end{array}$ & $\begin{array}{c}30.42 \\
\text { (1) }\end{array}$ & $\begin{array}{c}10.17 \\
\text { (1) }\end{array}$ & $\begin{array}{c}15.6 \\
(1)\end{array}$ & $\begin{array}{c}0.17 \\
\text { (3) }\end{array}$ & $\begin{array}{c}0.62 \\
(1)\end{array}$ & $\begin{array}{l}1.3 \\
\text { (P) }\end{array}$ & $\begin{array}{c}12,42 \\
7\end{array}$ & 612 & 1,642 & 4,634 & 5,283 & 4.4 \\
\hline
\end{tabular}

Note: $\mathrm{VG}=$ very good, $\mathrm{G}=\operatorname{good}, \mathrm{F}=$ fair and $\mathrm{P}=$ poor. $r / k=($ group $3+$ group 4$) /($ group $1+$ group 2).

Table 3: $\quad$ Parameter score and threshold criteria.

\begin{tabular}{|c|c|c|c|}
\hline & \multicolumn{3}{|c|}{ Parameter values criteria } \\
\hline Parameter & $\begin{array}{c}\mathbf{1} \\
<\mathrm{a}_{\mathrm{i}} \text { or }>\mathrm{b}_{\mathrm{i}}\end{array}$ & $\begin{array}{c}\mathbf{3} \\
\left(\text { bet. } \mathrm{a}_{\mathrm{i}} \text { and } \mathrm{b}_{\mathrm{i}}\right)\end{array}$ & $\begin{array}{c}\mathbf{5} \\
>\mathrm{b}_{\mathrm{i}} \text { or }<\mathrm{a}_{\mathrm{i}}\end{array}$ \\
\hline $\begin{array}{c}\text { Average monthly variation of } \\
\mathrm{NO}_{3}+\mathrm{NH}_{4} \mathrm{~N}\left(\mathrm{mg} \mathrm{l}^{-1}\right)\end{array}$ & $>=0.245$ & $0.16-0.245$ & $<=0.16$ \\
\hline Average monthly variation of $\mathrm{pH}$ & $>=0.5$ & $0.325-0.5$ & $<=0.325$ \\
\hline TSS concentration $\left(\mathrm{mg} \mathrm{l}^{-1}\right)$ & $>=66.53$ & $57.92-66.53$ & $<=57.92$ \\
\hline Water temperature $\left({ }^{\circ} \mathrm{C}\right)$ & $>=30.19$ & $29.89-30.19$ & $<=29.89$ \\
\hline Conductivity $(m S / m)$ & $>=8.87$ & $8.03-8.87$ & $<=8.03$ \\
\hline Ratio of $\mathrm{N} / \mathrm{P}$ & $>=11.66$ & $8.75-11.66$ & $<=8.75$ \\
\hline
\end{tabular}

The Pearson correlation tests between WQI and total 'dai' fish catch and fish species biological groups showed that the WQI was significantly correlated with total 'dai' fish catch $(\mathrm{r}=0.858)$ and fish biological group 4 ( $r$ species) $(\mathrm{r}=$ 0,750). The changes of WQI and total 'dai' fish catch during $1995-2002$ were shown in Figure 6. At the $k$ and $r$ fish species biological family level, the WQI 
were positively correlated with Ciprinidae family of group $4(\mathrm{r}=0.736 ; \mathrm{P}=$ $0.019)$ and negatively correlated with Gyrinocheilidae of group $3(\mathrm{r}=-0.829 ; \mathrm{P}=$ 0.006) indicated that these fish families are sensitive response to the WQI. The individual parameter threshold values criteria are shown in Table 3. In general, the TS ecosystem water quality condition would be changed from good to poor conditions due to a small amount variation of water quality parameters.

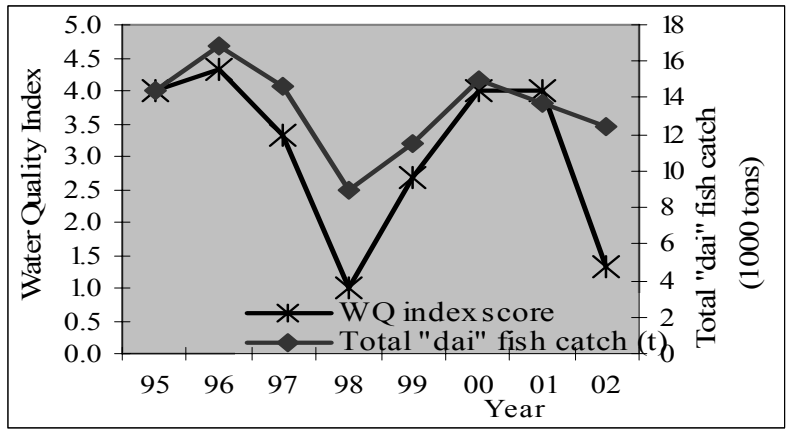

Figure 6: Changes of WQI and 'dai' fish catches in years.

\section{Discussion}

Six critical parameters are selected to constitute the TS ecosystem WQI. DO parameter is not selected to combine the WQI due to having low correlation coefficient with 'dai' fish catch on component 1 (Figure 4a), although it was said as an important factor affect the TS ecosystem fish production, Lambert [12]. As the criteria of parameter selection in method section, the concentration of TSS and conductivity are selected instead of their monthly variations to constitute the index. Low correlation coefficients with total 'dai' fish catch on component 1, the $\mathrm{NO}_{3}+\mathrm{NH}_{4} \mathrm{~N}$ concentration and $\mathrm{pH}$ were not selected to combine the index, however, their average monthly variations were selected to combine the index, because they were highly correlated with total 'dai' fish catch (Figure 5(a)). The strong correlation $(\mathrm{P}<0.01)$ between constituted WQI and total 'dai' fish catch indicates that the index enables reflecting the relation between water quality condition and fish production. Then the index should be considered to use as the water quality monitoring tool for the water quality - fish production assessment. The correlation $(\mathrm{P}<0.05)$ between WQ index and $r$ fish biological group 4, indicates that the $r$ fish biological species is more sensitive response to and impacted by the change of water quality environment. The highest WQI in 1996 (4.3) may support to explain the higher fish catch/production in this year. Inversely, the low WQI (1.3) would indicate why there was a low fish catch in 2002, although the hyroecological index is high at 4.3 in this year, Nguyen et al [14]. Those hypotheses should be studied more together with other aspect such as fish spawning and nursing grounds in the TS Lake. Two $r$ species families of Gyrinocheilidae and Cyprinidae should be selected as the TS ecosystem water quality bioindicators, because they are very sensitively responding to WQI. 
The TS ecosystem water quality are characterized by three different zones: (1) river zone represented by PP and PK stations, where is more directly influenced by Mekong main stream; (2) lake river delta zone represented by KC station, where is influenced both Mekong inflow and TS lake outflow and (3) lake zone represented by the KL station, where it is more influenced by the TS Lake catchments runoff. Of which, lake delta rive zone $\mathrm{KC}$ is the most complex multi-relationship among water quality parameters (Figure 3). Perhaps, because of its location at the transition zone between lake and river and located at the end loading point of the very large $181,035 \mathrm{~km}^{2}$ of the TS Lake catchments. The internal multi-relationship among parameters at KL station is quite different from the rest three stations. Moreover, the station external relationship: there is no correlation of $\mathrm{pH}$ between $\mathrm{PK}$ and $\mathrm{KL}$ station; the correlation of DO is just formed between PP and PK stations within the river zone. Then the lake zone (KL station) is apparently characterized by the lake catchments locality. The KL station has the best water quality condition; this perhaps is due to the important function of lake inundated forest and scrub in absorbing nutrient load from the water environment. However, this hypothesis should be studied more. Importantly, the small amount change of water quality parameter concentrations would be remarkably influencing on fish production, especially the very small change of $\mathrm{NO}_{3}+\mathrm{NH}_{4} \mathrm{~N}, \mathrm{pH}$, and temperature $\left(1^{\circ} \mathrm{C}\right)$. The TSS concentration about $50 \mathrm{mg}^{-1}$ is good for water quality (Table 3). Although, The WUP-FIN hydrological model showed that $80 \%$ of sediment from Mekong inflow remained in the TS Lake and contributed a great amount of nutrient to the TS ecosystem Surkkula et al [2], however, there is no correlation of TSS between KL station and PP and PK station, and no correlation between TSS and $\mathrm{NO}_{3}+\mathrm{NH}_{4} \mathrm{~N}$ in PP and PK. Then the study about the TS ecosystem nutrient sources should be more considered. The ratios between $\mathrm{N}$ and $\mathrm{P}$ falling down between 7 and 15 indicate that the TS ecosystem is in the mesotrophic condition (based on criteria of UNEP, www.unep.or.jp). The concentration of $\mathrm{NO}_{3}+\mathrm{NH}_{4} \mathrm{~N}$ and $\mathrm{pH}$ are not much varied during the sample period (low correlation coefficient on component 1) indicates that there is no eutrophication phenomenon in the TS ecosystem; this is similar with some previous research, Sarkkula et al [2]. The WQI are high (4) in 2000 and 2001, additionally, the hydroecological index are high in these years (5 and 4.2 respectively), Nguyen et al [14]. However, the decreasing of ratios between $r$ and $k$ species groups indicates that the TS ecosystem ecological process is diverging to inefficient energy flow at the lower trophic level $(r$ species) and then lack of food for the higher trophic level ( $k$ species). Then to be better understood about the TS ecosystem ecological process, other relative aspect such as fishing practice, catchments land use and trophic level should be paid more attention.

\section{Acknowledgements}

We would like to express our thanks to Sunada CREST and COE Programs, University of Yamanashi, Japan in funding for this research. Thank to MRC, WUP-FIN and Fisheries Department of Cambodia in providing data. 


\section{References}

[1] Mok, M., B. Neou \& B. D. Lane (2001). Biodiversity Conservation and Social Justice in the Tonle Sap Watershed: The Tonle Sap Biosphere Reserve. International Conference on Biodiversity and Society, UNESCO, 22-25 May 2001.

[2] Sarkkula, J., J. Koponen, S. Hellsten, M. Keskinnen, M. Kiirikki, L. Hannu and O. Varis (2003). Modelling Tonle Sap for Environmental Impact Assessment and Management Support. Water Utilization ProgramModelling of the Flow Regime and Water Quality of the Tonle Sap.

[3] Csavas, I., D. J. Doulman, T. O. Petr, J. Prado \& L. Debas, 1994. Cambodia - Rehabilitation and development needs of the fishery sector. FAO Fisheries Circular Nr. 873, FAO, Rome.

[4] WB, 1995. Cambodia agricultural productivity improvement project. Fisheries subproject. Phnom Penh.

[5] Ahmed, M., H. Navy, L. Vuthy \& M. Tiongco, 1998. Socioeconomic assessment of freshwater capture fisheries in Cambodia: report on a household survey. MRC, Phnom Penh, $186 \mathrm{p}$.

[6] Hak, M. \& N. Piseth (1999). Review of flooding and flood management in Cambodia: Cambodia country statement. In Flood management and mitigation in the Mekong river basin. Proceedings of the Regional Workshop, Vientiane 19-21 March 1998, RAP Publication 1999/14, FAO, Bangkok, pp. 29-38.

[7] MRC. 2003. State of the Basin Report: 2003. Mekong River Commission, Phnom Penh, 316 pages. ISSN: 1728:3248

[8] Chu. H. T., Guttman. H., Droogers. P and Aerts. J. 2003. Water, Climate, Food, and Environment in the Mekong basin in Southeast Asia. Final report, Contribution to the project ADAPT Adaptation strategies to changing environments IWMI, MRCS and IVM.

[9] MRC and UNEP, 1997. Mekong River Basin diagnostic study. Final report. Mekong River Commission (MRC), Bangkok, Thailand and United Nations Environment Programme (UNEP).

[10] ADB, 2004, Cambodia Country Environmental Analysis.

[11] UNEP/EAS/RCU. 1999. National Report of Cambodia on the formulation of a Transboundary Diagnostic Analysis and preliminary framework of a Strategic Action programme for the South China Sea.122pp. UNEP, Bangkok, Thailand.

[12] Lamberts, D. (2001). Tonle Sap Fisheries: A case study on floodplain gillnet fisheries, Asia-Pacific. Fishery Commission, FAO, Bangkok, Thailand.

[13] EPA Redbbok

[14] Nguyen, T. H.Y., Sunada. K., Oishi. S and Ikejima. K. 2006. Tonle Sap ecosystem fish biological groups and hydro-ecological index. Conference proceedings of Mekong Research for the Mekong People, Chaing Rai, Thailand Oct, 2006. 